\title{
Analisis Pemetaan Jaringan Komunikasi Karyawan Menggunakan Social Network Analysis Pada Perusahaan Multifinance
}

Network Mapping Analysis Communication Employees Use Social Network Analysis at Multifinance Companies

Diterima:

15 Maret 2019

Revisi:

12 Juni 2019

Terbit:

1 Juli 2019

\author{
${ }^{1}$ Edwin Zusrony, ${ }^{2}$ Hindriyanto Dwi Purnomo, ${ }^{3}$ Sri Yulianto \\ Joko Prasetyo \\ ${ }^{1,2,3}$ Magister Sistem Informasi, Universitas Kristen Satya Wacana \\ ${ }_{1,2,3}$ Salatiga, Indonesia \\ E-mail:. \\ ${ }^{2}$ hindriyanto.purnomo@staff.uksw.edu, sri.yulianto@uksw.edu
}

\begin{abstract}
Abstrak-Pengembangan bisnis di sektor jasa keuangan meningkatkan kompetisi di antara perusahaan untuk memberikan layanan terbaik kepada pelanggan mereka. Memiliki layanan yang dapat diandalkan dengan jaringan komunikasi yang baik dalam organisasi adalah keberhasilan penting perusahaan. Penelitian ini bertujuan untuk menemukan aktor atau orang yang mempengaruhi organisasi melalui jaringan komunikasi formal dan informal menggunakan Analisis Jejaring Sosial (SNA). Informasi tentang jaringan komunikasi kasual dan formal dapat digunakan oleh departemen SDM untuk mengukur tingkat hubungan sosial semua karyawan yang dapat meningkatkan kinerja mereka di perusahaan. Penulis meneliti PT. BFI Salatiga. Hasil penelitian menunjukkan bahwa kepadatan jaringan di bawah 50\% sehingga hubungan dianggap lemah. Aktor yang paling dominan dalam derajat sentralitas, sentralitas kedekatan, dan sentralitas hubungan adalah aktor id \# 24 dan id \# 29 dari divisi pengumpulan, aktor id \# 27 dari divisi operasi dan aktor id \# 30 dari divisi kredit.
\end{abstract}

Kata Kunci-SNA, Multifinance, Jaringan Komunikasi

\begin{abstract}
Business development in the financial services sector improved competition among companies to give the best service to their customers. Having reliable services with a good communication network in the organization is the critical success of the company. This study aims to find the actors or people who influence organizations through formal and informal communication networks using Social Network Analysis (SNA). Information on casual and formal communication networks can be used by the HR department to measure the level of the social relationship of all employees that can improve their performance in the company. The author researched PT. BFI Salatiga. The results showed that tissue density was below 50\% so that relationships were considered weak. The most dominant actor in degree centrality, closeness centrality, and betweenness centrality is the actor id\#24 and id\#29 from the collection division, actor id\#27 from the operation division and actor id\#30 from the credit division.
\end{abstract}

Keywords-SNA, Multifinance, Communication Network 
INTENSIF, Vol.3 No.2 August 2019

ISSN: 2580-409X (Print) / 2549-6824 (Online)

DOI: https://doi.org/10.29407/intensif.v3i2.12786

\section{PENDAHULUAN}

Perkembangan dunia usaha dimana khususnya pada sektor jasa keuangan memicu adanya persaingan antar beberapa lembaga keuangan untuk memberikan pelayanan produk yang baik dan prima. Dalam mewujudkan pelayanan yang baik serta prima sangat dibutuhkan kinerja perusahaan yang baik (good corporate) dimana akan terwujud apabila organisasi bisa mengendalikan hambatan-hambatan dalam komunikasi, khususnya internal stakeholder.

Berdasarkan penelitian yang dilakukan [1], dimana jaringan komunikasi dalam sebuah perusahaan jasa "The Piano Institute", disana terlihat jaringan komunikasi dalam organisasi dibagi menjadi jaringan informasi formal dan informal. Hasil penelitian didapatkan semua stakeholder internal perusahaan tersebut menjalankan dua jaringan informasi formal dan informal, tetapi tidak dijabarkan secara detail.

Dalam penelitian [2], yang mencoba meneliti tentang jaringan komunikasi informal pada PT. Damco Indonesia, dimana hasilnya terdapat 5 klique dalam jaringan komunikasi internal. Komunikasi informal menjadi wadah bagi karyawan untuk mengungkapkan segala aspirasi terkait dengan sallary, benefit, incentive, office facilities, division of work, partner and boss. Hal ini sebagai sarana untuk mereka bertukar pikiran untuk menyelesaikan masalah dalam pekerjaan.

Beberapa penelitian juga menunjukan tentang pola jaringan komunikasi informal yang tersembunyi dan tidak diakui oleh manajemen perusahaan. Teknik pengolahan data menggunakan Social Network Analysis (SNA), dimana sampel dan populasi adalah seluruh internal stakeholder perusahaan produksi kain Batik "UKM Windasari" di kabupaten Sragen, Jawa Tengah [3]. Dimana hasil dari riset menunjukkan hanya 3 aktor yang memiliki peran besar dan banyak aktor yang bergantung dalam menjadi perantara dengan aktor-aktor lainnya, sehingga pola hubungan komunikasi ini tidak mendukung kerjasama yang baik.

Dalam hal ini peneliti ingin berusaha melakukan riset terkait jaringan komunikasi informal pada perusahaan multifinance yaitu PT.BFI Finance Tbk. yang memiliki salah satu cabang potensial di area propinsi Jawa Tengah yaitu di kota Salatiga, dimana pertumbuhan aset yang selalu meningkat tiap tahun dari awal berdiri di tahun 2013 [4]. Pertumbuhan aset perusahaan diiringi penambahan jumlah man power atau karyawan baru, dimana hal ini juga menjadi tantangan perusahaan dalam mengontrol kinerja stakeholder internal khususnya dalam hal jaringan komunikasi.

PT. BFI Finance cabang Salatiga selama ini sudah memiliki struktur organisasi yang mengatur tugas, tanggung jawab dan wewenang individu dan menjadi acuan komunikasi formal dalam perusahaan. Dalam hal jaringan komunikasi formal dilihat selama ini tidak terlalu ada 
INTENSIF, Vol.3 No.2 August 2019

ISSN: 2580-409X (Print) / 2549-6824 (Online)

DOI: https://doi.org/10.29407/intensif.v3i2.12786

kendala yang signifikan, tetapi dalam jaringan komunikasi informal yang selama ini kurang bisa dianalisis dan di petakan karena diluar struktur organisasi formal, dimana selama ini tidak ada review dari Human Capital (Departemen SDM) terkait komunikasi informal.

Komunikasi memiliki pengaruh terhadap kinerja karyawan [5], dimana jaringan komunikasi di sebuah organisasi terkadang terdapat masalah dalam komunikasi, dimana hal ini dapat menjadi penghambat dalam kinerja organisasi yang dampaknya juga akan mengarah pada pencapaian tujuan organisasi itu sendiri. Penggunaan SNA (social network analysis) sebagai salah satu metode yang memberikan kesempatan untuk melihat pola komunikasi tersembunyi dari interaksi informal [3], seperti menyelidiki aktor dan kelompok, baik yang memiliki struktur organisasi formal maupun informal untuk dapat dilakukan pemetaan dan analisa oleh HRD, khususnya mencari tahu individu yang dianggap berperan penting (key actor) dan akan membantu memudahkan HRD dalam memberikan informasi terkait pola hubungan sosial yang baik dalam work area, sehingga akan meningkatkan kinerja karyawan secara signifikan serta membuat alur komunikasi lancar dalam perusahaan.

\section{METODE PENELITIAN}

\section{A. Pengumpulan Data}

Penelitian ini menggunakan metode survei kuesioner. Data dikumpulkan berasal dari seluruh populasi karyawan (aktor/individu) sebuah perusahaan multifinance. Pemilihan responden dimulai dengan beberapa individu (aktor) yang merupakan seorang karyawan. Sampel yang diambil adalah keseluruhan populasi atau dengan kata lain semua karyawan yang merupakan individu (aktor) dengan teknik snowball sampling, yaitu metode pengambilan sampel dengan mengambil subjek awal sebagai benih (jumlah kecil) dan menyebutkan subjek kedua dan seterusnya sampai jumlah sampel terpenuhi secara berantai seperti bola salju [6].

Hasil dari kuesioner kemudian ditabulasikan dalam matriks hubungan dan matriks atribut dalam format Microsoft Excel (apabila ada relasi diberi nilai nol dan apabila ada relasi diberi nilai satu). Data yang sudah di tabulasi di Microsoft Excel kemudian dipindahkan (export) dalam aplikasi UCINET 6 dan NetDraw yang dikembangkan oleh Analytic Technologies untuk dianalisis lebih lanjut [7] dalam [8]. Peneliti menggunakan materi kuesioner pertanyaan tentang jaringan komunikasi dibagi dalam dua bagian, yaitu: name generator (menyebutkan aktor yang memiliki relasi dengan responden) dan name interpreter (mengkonfirmasi relasi aktor yang disebutkan oleh responden) [9]. Dalam penyebaran kuesioner dibagi menjadi 2 bagian, dimana kuesioner pertama dengan 4 item pertanyaan dan kuesioner kedua dengan 8 item pertanyaaan. 
INTENSIF, Vol.3 No.2 August 2019

ISSN: 2580-409X (Print) / 2549-6824 (Online)

DOI: https://doi.org/10.29407/intensif.v3i2.12786

Dalam melakukan tahapan dan implementasi penelitian, tahapan metodologi penelitian dijabarkan pada gambar 1.

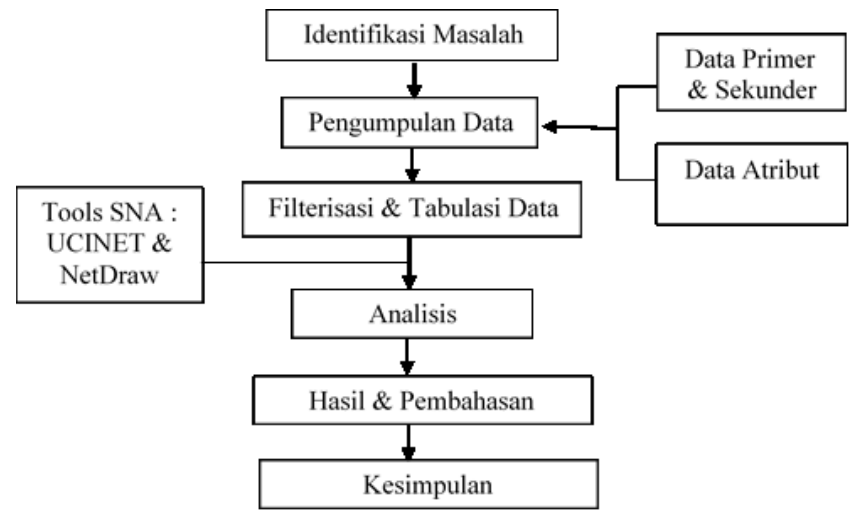

Gambar 1. TAHAPAN PENELITIAN

\section{B. Social Network Analysis (SNA)}

Jaringan sosial adalah struktur sosial yang terdiri dari sekelompok aktor sosial, individu atau organisasi, dan serangkaian hubungan antara para aktor [10], [8]. Perspektif jaringan sosial menyediakan metode untuk menganalisis struktur entitas sosial secara keseluruhan serta teori yang menjelaskan pola yang diamati dalam struktur ini. Analisis jejaring sosial adalah alat untuk menganalisis struktur hubungan sosial dalam suatu kelompok. SNA mengungkap pola, memetakan hubungan antara individu, dan secara bersamaan memvisualisasikan hubungan antara para aktor. SNA juga bisa digunakan dalam penyebaran isu-isu terbaru atau trend [11].

Elemen-elemen dalam social network analysis (SNA) ada tiga kategori [8], yaitu group yang merupakan kumpulan aktor dalam sebuah organisasi dengan ukuran kelompok yang bervariasi antara $25 \mathrm{~s} / \mathrm{d} 200$ orang, kemudian ada interaction yang merupakan pola hubungan atau interaksi antar aktor dalam suatu organisasi atau komunitas, dan yang terakhir adalah atribut yang merupakan kelengkapan / fitur yang dimiliki oleh aktor, seperti usia, gender, dan jabatan).

\section{System Level: Structure and Character}

Level sistem merupakan penggambaran jaringan secara komprehensif, dimana tidak hanya berbicara tentang aktor atau kelompok (group) dalam suatu jaringan tetapi lebih melihat karakteristik dan struktur jaringan [12]. Density merupakan salah satu parameter untuk mengukur karakteristik dan struktur jaringan dengan membandingkan jumlah link yang ada dalam jaringan dengan jumlah link yang muncul [12]. Jaringan dengan kepadatan (density) tinggi menunjukkan bahwa semua aktor saling berinteraksi dengan aktor yang lain dan nilai dalam density antara 0 hingga 1, dimana makin besar nilai akan menuhjukkan tingginya density 
[13]. Pengukuran density terdiri dari komponen D adalah kepadatan (density), I adalah jumlah link aktual dalam jaringan, dan $\mathbf{N}$ adalah ukuran jaringan (jumlah aktor dalam jaringan). Rumus density yang terdapat dalam persamaan (1) dibawah ini:

$$
D=\frac{l}{N(N-1)}
$$

\section{Metode Pengukuran Centrality}

Untuk menguji hubungan antara individu dalam suatu kelompok dalam sebuah organisasi maupun perusahaan [14], SNA memiliki beberapa metode pengukuran centrality meliputi: a. Degree Centrality: tingkatan (degree) yang menunjukkan popularitas aktor dalam jaringan sosial. Tingkatan (degree) adalah jumlah link (relasi diantara aktor) dari dan ke aktor (individu) [13], [15], [12]. Ukuran ini menunjukkan posisi individu dalam jaringan, dimana dalam jaringan yang directed (mempunyai arah) individu atau aktor yang populer akan sering dihubungi (indegree) maupun menghubungi (outdegree) [12]. b. Closeness Centrality: sentralitas kedekatan (keperentaraan) menggambarkan penghitungan jalur terpendek (shorted path lengths) dari satu aktor (node) ke aktor (node) yang lain. Pengukuran closeness centrality dari berapa banyak langkah (jalur/path) seorang aktor bisa menghubungi atau dihubungi oleh aktor lain dalam jaringan [13], [15], [12]. Aktor (node) ini dapat menyebarluaskan informasi lebih lebih cepat serta memiliki lebih sedikit perantara. c. Betweenness Centrality: menunjukkan posisi aktor (node) sebagai perantara (betweenness) dari hubungan aktor (individu) satu dengan aktor lain (individu) [12]. Aktor yang memiliki betweenness centrality paling tinggi adalah yang memiliki kemampuan penghubung yang baik antar aktor dalam sebuah jaringan [16], serta memegang kontrol manipulasi atas informasi.

Dalam degree centrality rumus yang digunakan ada dalam persamaan (2) dan terdiri dari komponen $\mathbf{C}_{\mathbf{d}}$ adalah nilai degree centrality, $\mathbf{d}_{\mathbf{1}}$ adalah jumlah ties / link / edge (relasi diantara aktor) dari dan ke aktor / individu / node, dan $\mathbf{N}$ adalah jumlah seluruh anggota populasi (aktor/individu). Ilustrasi dalam degree centrality dapat dicontohkan apabila ada populasi berjumlah 100 orang, maka maksimal link (relasi diantara aktor/individu) yang bisa dijalin adalah 99 orang (N-1) [12].

Pengukuran closeness centrality untuk rumus yang digunakan ada dalam persamaan (3) yang terdiri dari komponen $\mathbf{C}_{\mathbf{c}}$ adalah nilai closeness centrality, $\mathbf{D}$ adalah jalur (path) terpendek ke aktor lain, dan $\mathbf{N}_{\mathbf{i j}}$ adalah jumlah seluruh anggota populasi (individu). Semakin tinggi nilai closeness centrality maka semakin memperlihatkan dekatnya rata-rata aktor dengan seluruh aktor lain atau dengan kata lain aktor (node) yang memiliki nilai closeness centrality paling besar adalah aktor (individu) yang bisa menjangkau aktor lain (individu lain) secara lebih cepat karena memiliki jalur terpendek (shorted path lengths) [12]. 
INTENSIF, Vol.3 No.2 August 2019

ISSN: 2580-409X (Print) / 2549-6824 (Online)

DOI: https://doi.org/10.29407/intensif.v3i2.12786

Sedangkan pengukuran betweenness centrality rumus yang digunakan ada dalam persamaan (4), dimana terdiri dari komponen $\mathbf{C b}$ adalah nilai keperantaraan (betweenness centrality), $\mathbf{g}_{\mathbf{i j}} \mathbf{P}_{\mathbf{k}}$ adalah jumlah jalur terpendek (shorted path lengths) dari aktor, $\mathbf{g}_{\mathbf{i j}}$ adalah merupakan jumlah jalur (path) dalam jaringan, dan $\mathbf{N}^{\mathbf{2}} \mathbf{- 3 n}+\mathbf{2}$ adalah nilai maksimum. Nilai betweenness centrality (normal) adalah antara 0-1, dimana mendekati 1 yang paling bagus. Perhitungan betweenness centrality, pertama menentukan kemungkinan interaksi antara aktor satu dengan aktor lainnya, kedua menentukkan jalur terpendek (shorted path lengths) ketika salah satu aktor (node) berhubungan dengan aktor (node) lain melewati aktor tertentu atau tidak, dimana kalau tidak melewati aktor tertentu, nilainya nol (0) [11], [14] dalam [12]. Sebagai ilustrasi jika untuk melewati suatu aktor hanya ada satu kemungkinan maka nilainya 1, dan bila terdapat dua kemungkinan jalur (path) maka nilainya $0,5(1 / 2)$, serta bila terdapat tiga kemungkinan jalur (path) maka nilainya 0,3 (1/3), dan begitu seterusnya [12]. Berikut rumus persamaan centrality dalam SNA (degree, closenness, and betweenness) :

$$
\begin{aligned}
& c_{s}=\sum \frac{d_{i}}{N-1} \\
& C_{c}=\frac{\mathrm{N}-1}{\sum D_{i j}} \\
& C_{b}=\frac{\frac{g_{i j, B_{K}}}{g_{i j}}}{N^{2}-3 n+2}
\end{aligned}
$$

\section{E. Clique}

Clique merupakan pengelompokan aktor di dalam suatu jaringan dimana memasukkan (maksimal) semua bentuk relasi (hubungan) diantara aktor, dan aktor-aktor (node) tersebut saling berinteraksi satu dengan yang lain dengan semua anggota atau kelompoknya [17], [18]. Ada dua ciri utama dalam clique (klik), dimana yang pertama adalah saling keterhubungan diantara sesama aktor dan yang kedua adalah memasukkan semua hubungan (interaksi) secara maksimal atau tanpa dikurangi, dimana jumlah anggota dalam clique tidak ada batasan, dimana yang diutamakan adalah setiap aktor memiliki relasi yang lengkap [19]. Clique dalam SNA sering disebut juga kumpulan jaringan komunikasi antar individu karena persamaan latar belakang, persamaan hobi, persamaan pekerjaan, dll. Jumlah minimal hubungan dalam clique minimal 3 orang individu yang saling menghubungi dan dihubungi, sehingga dalam perusahaan sering disebut geng [12]. 


\section{F. Graf}

Graf merupakan struktur jaringan yang berguna untuk memodelkan hubungan relasional antara objek (aktor), dimana dalam social network analysis (SNA) menggunakan jenis graf yang berisi node atau titik (aktor) untuk mempresentasikan hubungan yang disebut sociogram [20]. Dalam menggambarkan relasi hubungan dalam graf disimbolkan dengan edges (path) yaitu directed graph (graf terarah), dimana directed graph ini mampu memperlihatkan hubungan relasi yang jelas antar aktor dan disimbolkan dengan edge (path) yang digambarkan dengan anak panah [20]. Dengan adanya gambaran model hubungan jaringan komunikasi menggunakan sociogram maka akan membantu organisasi atau perusahaan dalam memetakan dan menganalisis key actor yang berperan dalam penyebaran informasi secara efektif dan dapat membantu manajemen serta mendukung peningkatan kinerja SDM melalui peran key actor.

\section{HASIL DAN PEMBAHASAN}

\section{A. Density}

Pada tabel 1 menunjukkan hasil perhitungan menggunakan UCINET 6 untuk statistik deskriptif. Jumlah koefisien pada baris ketiga Tabel 1 menunjukkan bahwa ada 156 ikatan (network) yang terjadi dalam jaringan. Sedangkan jumlah koefisien pada tabel 2 menunjukkan bahwa ada 272 ikatan (network) yang terjadi pada jaringan .

Rata-rata density dalam jaringan sebesar 12,4\% pada tabel 1 dan sebesar 21,6\% pada tabel 2, yang berarti kepadatan kurang dari 50\% [12]. Dengan perbedaan yang signifikan antara ikatan yang terjadi dan ikatan total yang dapat terjadi, dapat disimpulkan kemungkinan bahwa hubungan antara individu dalam jaringan ini lemah.

Tabel 1. DENSITY (1)

\begin{tabular}{ccc}
\hline \multicolumn{3}{c}{ Density / Average Matrix Value } \\
\hline 1. Density & 2. No. of ties & 3. Avg Degree \\
\hline 0,124 & 156 & 4,333 \\
\hline
\end{tabular}

Tabel 2. DENSITY (2)

\begin{tabular}{rcr}
\hline \hline \multicolumn{3}{c}{ Density / Average Matrix Value } \\
\hline 1. Density & 2. No. of ties & 3. Avg Degree \\
\hline 0,216 & 272 & 7,566 \\
\hline
\end{tabular}


INTENSIF, Vol.3 No.2 August 2019

ISSN: 2580-409X (Print) / 2549-6824 (Online)

DOI: https://doi.org/10.29407/intensif.v3i2.12786

\section{B. Degree Centrality}

Tabel 3 menunjukkan statistik deskriptif degree centrality, dimana ada 36 orang dalam jaringan, tetapi hanya beberapa individu yang memiliki tingkat sentralitas tinggi. Dalam tabel 3 , aktor id\#A30 adalah individu dengan nilai sentralitas tertinggi dengan nilai sembilan untuk outdegree (menghubungi) dan sepuluh untuk indegree (dihubungi) [12]. Ini menunjukkan bahwa individu id\#A30 mengirim informasi kepada 9 orang di dalam jaringan dan menerima informasi dari 10 orang lain.

Sedangkan pada tabel 4, aktor id\#A29 adalah individu dengan nilai sentralitas tertinggi dengan nilai sembilan untuk outdegree (menghubungi) dan sepuluh untuk indegree (dihubungi), dalam hal ini menunjukkan bahwa individu id\#A29 mengirim informasi kepada 17 orang di dalam jaringan dan menerima informasi dari 16 orang lain [12].

Dalam hal tingkat keseluruhan, kombinasi dari outdegree dan indegree, individu id\#A30 (tabel 3) dan individu id\#A30 (tabel 4) memiliki tingkat tertinggi dari semua individu dalam jaringan. Ini berarti bahwa individu id\#A30 memiliki pengaruh besar baik dalam hal menyampaikan informasi maupun dalam hal menerima informasi dari orang lain . Karena itu, individu id\#A30 memiliki posisi yang sangat penting dalam kolaborasi antar aktor atau individu.

Tabel 3. DEGREE CENTRALITY (1)

\begin{tabular}{lcccc}
\hline \hline \multicolumn{4}{c}{ Freeman's Degree Centrality Measures } \\
\hline ID & OutDegree & InDegree & NrmOutDeg & NrmInDeg \\
\hline A30 & 9.000 & 10.000 & 25.714 & 28.571 \\
A24 & 9.000 & 9.000 & 25.714 & 25.714 \\
A9 & 8.000 & 8.000 & 22.857 & 22.857 \\
A26 & 8.000 & 8.000 & 22.857 & 22.857 \\
A6 & 7.000 & 7.000 & 20.000 & 20.000 \\
\hline
\end{tabular}

Tabel 4. DEGREE CENTRALITY (2)

\begin{tabular}{lcccc}
\hline \hline \multicolumn{5}{c}{ Freeman's Degree Centrality Measures } \\
\hline ID & OutDegree & InDegree & NrmOutDeg & NrmInDeg \\
\hline A29 & 17.000 & 16.000 & 48.571 & 45.714 \\
A27 & 16.000 & 17.000 & 45.714 & 48.571 \\
A30 & 15.000 & 16.000 & 42.857 & 45.714 \\
A13 & 11.000 & 10.000 & 31.429 & 28.571 \\
A10 & 11.000 & 11.000 & 31.429 & 31.429 \\
\hline
\end{tabular}

152 INTENSIF: Jurnal Ilmiah Penelitian dan Penerapan Teknologi Sistem Informasi 
INTENSIF, Vol.3 No.2 August 2019

ISSN: 2580-409X (Print) / 2549-6824 (Online)

DOI: https://doi.org/10.29407/intensif.v3i2.12786

\section{Closenness Centrality}

Dalam Tabel 5 ditunjukkan hasil perhitungan Closeness Centrality dari beberapa aktor dalam jaringan. Incloseness menunjukkan seberapa dekat individu lain dengan seseorang di dalam jaringan, sementara outcloseness menunjukkan seberapa dekat seseorang dengan individu lain dalam jaringan [12]. Dari perhitungan, individu id\#A29 memiliki nilai tertinggi dan posisi kedua ditempati oleh individu id\#A24.

Seperti yang ditunjukkan pada tabel 5 dan tabel 6, aktor id\#29 (tabel 5) dan id\#27 (tabel 6) yang memiliki outcloseness dan incloseness dengan nilai tertinggi [12]. Jaringan yang tidak simetris membuat dua nilai berbeda. Posisi kedekatan mereka dengan dan dari aktor lain dalam jaringan membuat kedua aktor mampu berinteraksi dengan cepat dengan banyak aktor.

Tabel 5. CLOSENESS CENTRALITY (1)

\begin{tabular}{lcc}
\hline \hline \multicolumn{3}{c}{ Closeness Centrality } \\
\hline ID & inCloseness & outCloseness \\
\hline A29 & 46.053 & 46.053 \\
A24 & 44.872 & 44.872 \\
A30 & 44.304 & 42.683 \\
A26 & 43.750 & 42.683 \\
A4 & 41.667 & 41.667 \\
\hline
\end{tabular}

Tabel 6. CLOSENESS CENTRALITY (2)

\begin{tabular}{lcc}
\hline \hline \multicolumn{3}{c}{ Closeness Centrality } \\
\hline ID & inCloseness & outCloseness \\
\hline A27 & 64.815 & 62.500 \\
A30 & 64.815 & 63.636 \\
A29 & 61.404 & 66.038 \\
A13 & 58.333 & 59.322 \\
A15 & 56.452 & 54.688 \\
\hline
\end{tabular}

\section{Betweenness Centrality}

Tampak pada tabel 4 menunjukkan hasil perhitungan betweenness centrality dari beberaapa aktor, dimana individu id\#A24 (tabel 7) dan individu id\#29 (tabel 8) yang memiliki nilai nBetweenness tertinggi, dimana angka-angka ini menunjukkan bahwa kedua individu (node) memiliki posisi favorit dalam jaringan, karena banyak aktor/individu bergantung pada mereka untuk membuat koneksi dengan aktor/individu lain [12].

Kedua aktor (node) ini memiliki berbagai jalur terpendek alternatif untuk menjangkau individu lain dalam menyampaikan informasi atau menerima informasi. Ini terjadi karena 
INTENSIF, Vol.3 No.2 August 2019

ISSN: 2580-409X (Print) / 2549-6824 (Online)

DOI: https://doi.org/10.29407/intensif.v3i2.12786

keduaa aktor (node) menempati posisi sebagai perantara bagi individu untuk berhubungan dengan individu lain.

Tabel 7. BETWEENNNESS CENTRALITY (1)

\begin{tabular}{lcc}
\hline \hline \multicolumn{3}{c}{ Freeman Betweenness Centrality } \\
\hline ID & Betweenness & nBetweenness \\
\hline A24 & 286.111 & 24.043 \\
A29 & 237.548 & 19.962 \\
A30 & 233.178 & 19.595 \\
A26 & 185.372 & 15.577 \\
A1 & 143.908 & 12.093 \\
\hline
\end{tabular}

Tabel 8. BETWEENNESS CENTRALITY (2)

\begin{tabular}{lcc}
\hline \hline \multicolumn{3}{c}{ Freeman Betweenness Centrality } \\
\hline ID & Betweenness & nBetweenness \\
\hline A29 & 199.111 & 16.782 \\
A27 & 195.567 & 16.434 \\
A30 & 160.019 & 13.447 \\
A1 & 61.894 & 5.201 \\
A13 & 51.543 & 4.331 \\
\hline
\end{tabular}

\section{E. Clique}

Dalam kuesioner pertama dihasilkan 1 clique dengan batasan minimal 5 jumlah anggota (tidak ada batasan baku) seperti yang ditunjukkan pada tabel 9 dan gambar 2 yang menunjukkan clique pada kuesioner pertama, dimana clique hanya menampung 5 aktor dari 36 aktor di dalam jaringan [12].

Tabel 9. CLIQUE (1)

\begin{tabular}{cc}
\hline Clique & Actor \\
\hline A & $5,9,10,23,30$ \\
\hline
\end{tabular}

154 INTENSIF: Jurnal Ilmiah Penelitian dan Penerapan Teknologi Sistem Informasi 


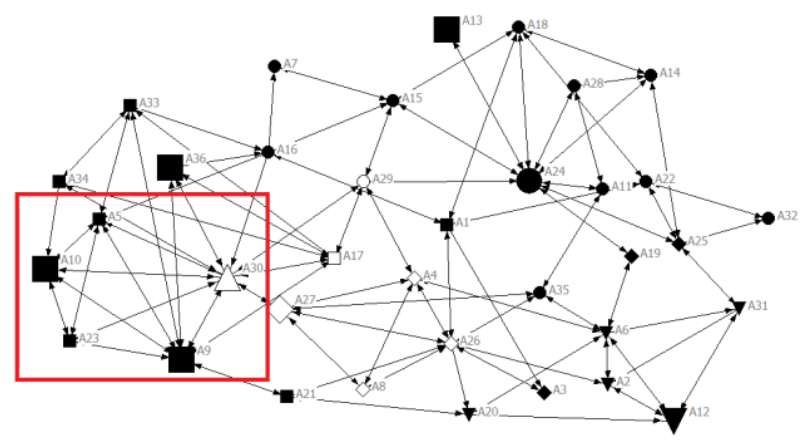

Gambar 2. CLIQUE DALAM JARINGAN

Dalam kuesioner kedua dihasilkan 10 clique dengan batasan minimal 5 jumlah anggota (tidak ada batasan baku) seperti yang ditunjukkan pada tabel 10 yang menunjukkan clique pada kuesioner kedua, dimana clique hanya menampung 27 aktor dari 36 aktor di dalam jaringan [12]. Dengan kata lain ada 9 aktor yang tidak termasuk dalam clique.

Tabel 10. CLIQUe (2)

\begin{tabular}{cl}
\hline Clique & \multicolumn{1}{c}{ Actor } \\
\hline A & $13,15,24,25,29$ \\
B & $22,24,25,29,32$ \\
C & $13,15,18,24,29$ \\
D & $7,15,16,18,29$ \\
E & $13,15,16,18,29$ \\
F & $13,15,16,29,30$ \\
G & $2,6,12,20,31$ \\
H & $1,3,19,26,27$ \\
I & $9,10,17,30,36$ \\
J & $13,15,16,27,30$ \\
\hline
\end{tabular}

F. Sociogram 1

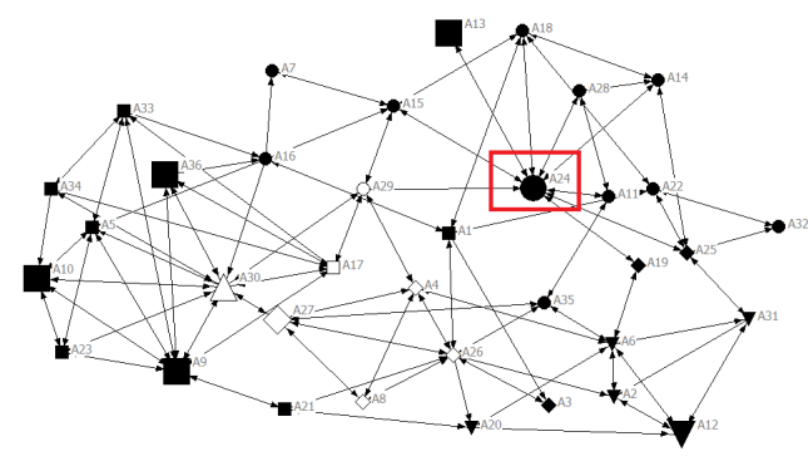

Gambar 3. SOCIOGRAM 1 (JENIS KELAMIN, JABATAN, DIVISI) 
INTENSIF, Vol.3 No.2 August 2019

ISSN: 2580-409X (Print) / 2549-6824 (Online)

DOI: https://doi.org/10.29407/intensif.v3i2.12786

Pada gambar 3 aktor pria lebih mendominasi dari segi kuantitas, tetapi aktor wanita lebih terkonsentrasi di pusat jaringan seperti pada id\#A30, id\#A29, id\#A26, dan id\#A4, dimana wanita juga tampil lebih aktif daripada pria. Berdasarkan gambar 3 diketahui supervisor yang paling banyak melakukan kolaborasi dengan para staff adalah aktor id\#A30 dan id\#A24. Sedangkan pada gambar 3, supervisor yang paling banyak melakukan kolaborasi dengan para staff adalah aktor id\#24, id\#27, dan id\#30. Aktor atau indivdu pada gambar 3 yang memiliki hubungan berbeda dengan struktur formalnya, yaitu id\#A13, id\#A1, id\#A19, dan id\#30 (independent division) [12].

Pada gambar 3 ini dapat pula dijabarkan rumus degree centrality dalam persamaan (1) dengan perbandingan hasil output dari software UCINET 6 [12]. Sebagai contoh aktor id\#24 dalam tabel 3 (diatas) memiliki outdegree (menghubungi) dan indegree dihubungi) sebanyak 9 aktor/individu. Dimana nilai outdegree dan indegree $\neg$ atau $\mathrm{d} 1=9, \mathrm{~N}=36$ sehingga apabila dimasukkan kedalam rumus $\mathrm{d} 1:(\mathrm{N}-1)=9 / 35=25,714$ (NrmOutDeg and NrmInDeg) [12].

Hubungan antara aktor berdasarkan atribut Jabatan dari masing-masing karyawan ditunjukan pada gambar 3 serta pada tabel 11, 12 dan 13 (dibawah). Pada tabel 11 terdapat simbol down triangle merupakan divisi motor, simbol square divisi mobil, simbol diamond divisi operasional, simbol circle divisi penagihan dan simbol up triangle divisi kredit.Untuk warna pada tabel 12 dibuat berdasarkan jenis kelamin, dimana warna white untuk wanita dan warna black untuk aktor pria. Sedangkan pada tabel 13 ukuran simbol untuk karyawan staff level ukuran simbolnya small dan karyawan supervisor level termasuk Branch Manager dengan id\#A13 ukuran simbolnya large.

Tabel 11. DIVISI, SIMBOL, DAN ID AKTOR

\begin{tabular}{llc}
\hline \hline Division & Symbol & Actor ID \\
\hline Mobil & Square & $1,5,9,10,13,17,21,23,33,34,36$ \\
Motor & Down Triangle & $2,6,12,20,31$ \\
Kredit & Up Triangle & 30 \\
Penagihan & Circle & $7,11,14,15,16,18,22,24,25,28,29$, \\
Operasional & Diamond & 32,35 \\
& & $3,4,8,19,26,27$ \\
\hline
\end{tabular}

Sumber: data diolah dari UCINET 6, 2019

Tabel 12. WARNA DAN JENIS KELAMIN

\begin{tabular}{cll}
\hline \hline Group & Gender & Colour \\
\hline 1 & Pria & Black \\
2 & Wanita & White \\
\hline
\end{tabular}

Tabel 13. SIMBOL DAN JABATAN

\begin{tabular}{ccc}
\hline \hline Group & Gender & Size \\
\hline 1 & SPV & Large \\
2 & Staff & Small \\
\hline
\end{tabular}

Sumber: data diolah dari UCINET 6, 2019

156 INTENSIF: Jurnal Ilmiah Penelitian dan Penerapan Teknologi Sistem Informasi 


\section{G. Sociogram 2}

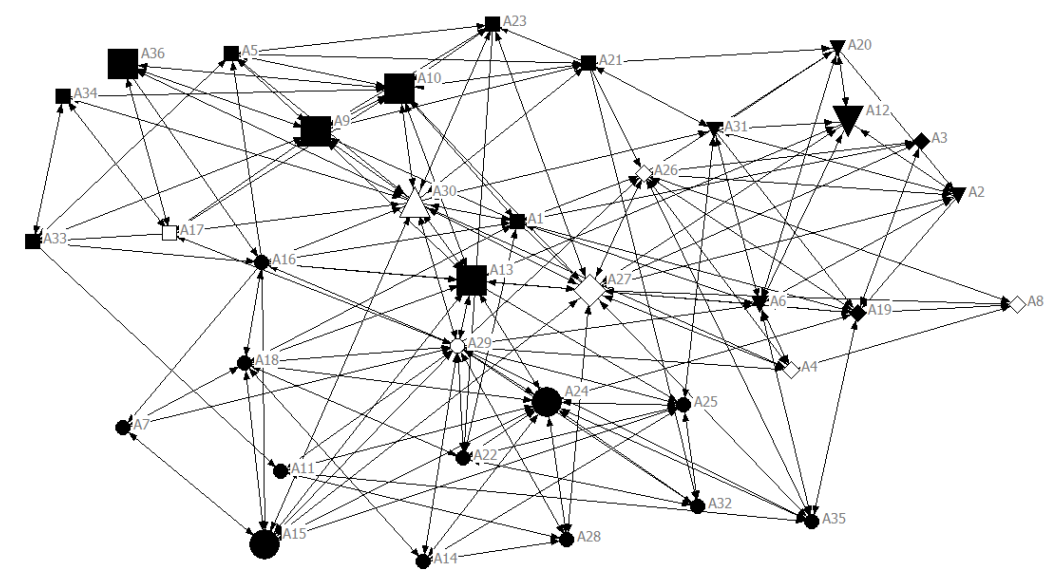

Gambar 4. SOCIOGRAM 2 (JENIS KELAMIN, JABATAN, DIVISI)

Pada gambar 4 aktor pria juga lebih mendominasi dari segi kuantitas dan aktor wanita juga terkonsentrasi di pusat jaringan seperti pada id\#4, id\#8, dan id\#26. Perbedaan yang mencolok terlihat dari jumlah hubungan yang semakin kompleks karena jumlah hubungan aktor bertambah karena adanya penambahan pertanyaan pada kuesioner kedua [12].

Berdasarkan gambar 4, diketahui supervisor yang paling banyak melakukan kolaborasi dengan para staff adalah aktor id\#A30 dan id\#A24. Sedangkan pada gambar 3, supervisor yang paling banyak melakukan kolaborasi dengan para staff adalah aktor id\#24, id\#27, dan id\#30. Sedangkan aktor pada gambar 3 yang memiliki hubungan berbeda dengan struktur formalnya, yaitu id\#A6, id\#A27, id\#A30, id\#A29, id\#A1, id\#A19, id\#A6 dan id\#A13.

\section{KESIMPULAN DAN SARAN}

Dalam penggunaan metode SNA menunjukkan hasil penelitian dalam memetakan dan menganalisis pola hubungan relasi yang tersembunyi, khususnya dalam jaringan komunikasi formal dan informal. Hasil penelitian menunjukkan kepadatan dalam jaringan atau density dibawah 50\%, sehingga secara ikatan dianggap lemah. Aktor yang paling sering dihubungi dengan nilai degree centrality tertinggi adalah aktor id\#30 dan id\#29. Sedangkan aktor yang memilki jangkauan terdekat dalam mencapai tingkatan aktor, yang ditunjukkan tingginya nilai closeness centrality adalah aktor id\#27 dan id\#29. Selanjutnya aktor yang memiliki kemampuan untuk menjadi penghubung kepada aktor-aktor lain adalah aktor id\#24 dan id\#29 yang ditunjukan tingginya nilai betweenness centrality. Dalam hal pengelompokkan aktor (clique) yang menggunakan batasan 5 anggota diperoleh hasil ada 10 clique. Rata-rata interaksi antar individu mengelompok pada divisi kerja masing-masing, hanya beberapa saja yang tidak sesuai. Diharapkan dengan hasil penelitian ini dapat menjadi titik awal menggali pola relasi hubungan sosial yang lebih luas dan kompleks. 


\section{DAFTAR PUSTAKA}

[1] M. Pengestu, "Jaringan Komunikasi di The Piano Institute Surabaya," E- Komunikasi, Univ. Kristen Petra Surabaya, vol. 3, pp. 1-12, 2015.

[2] Fitriani, "Analisis Jaringan Komunikasi Informal ' Adidas Team ' Di PT. Damco Indonesia Jakarta Pusat," J. Visi Komun., vol. 15, no. 2, pp. 275-285, 2016.

[3] A. Iriani and S. H. Priyanto, "Modeling Of Employee Relationships In Sme Batik: Case Study Of Windasari Batik," Asian J. Manag. Sci. Educ., vol. 2, no. 4, pp. 22-35, 2013.

[4] E. Zusrony, W. Kuncoro, and N. Nurrochman, "Pemetaan Persebaran Nasabah Kredit Macet Perusahaan Multifinance," INTENSIF, vol. 2, no. 2, p. 107, 2018.

[5] A. P. Wardhani, H. Leonardo Budi, and M. Maria Magdalena, "Pengaruh Lingkungan Kerja, Komunikasi dan Kepemimpinan Terhadap Kinerja Pegawai," J. Manage., vol. 2, no. 1, pp. 344-354, 2016.

[6] I. Etikan, "Comparision of Snowball Sampling and Sequential Sampling Technique," Biometrics Biostat. Int. J., vol. 3, no. 1, 2017.

[7] S. P. Borgatti, M. G. Everett, and L. C. Freeman, "Ucinet for Windows: Software for Social Network Analysis," Harvard Anal. Technol., vol. 2006, no. January, p. SNA Analysis software, 2002.

[8] B. E. Giri, D. Manongga, and A. Iriani, "Using Social Networking Analysis (SNA) to Analyze Collaboration between Students (Case Study: Students of Open University in Kupang)," Int. J. Comput. Appl., vol. 85, no. No. 1, pp. 44-49, 2014.

[9] S. P. Borgatti, D. J. Brass, and D. S. Halgin, "Social network research: Confusions, criticisms, and controversies," Res. Sociol. Organ., vol. 40, pp. 1-29, 2014.

[10] S. Wasserman and K. Faust, "Social network analysis: Methods and applications," Cambridge Univ. Press, vol. 1, p. 116, 1994.

[11] Q. Luo and D. Zhong, "Using social network analysis to explain communication characteristics of travel-related electronic word-of-mouth on social networking sites," Tour. Manag., vol. 46, pp. 274-282, 2015.

[12] Eriyanto, Analisis Jaringan Komunikasi, Edisi 1. Jakarta: Kencana, 2014.

[13] T. W. Valente, Social Networks and Health: Models, Methods, and Applications. 2010.

[14] H. Tuhuteru and A. Iriani, "Analisis Kolaborasi Penelitian Ilmiah Dosen Fakultas X dengan Social Network Analysis (SNA) Jurnal Teknik Informatika dan Sistem Informasi," J. Tek. Inform. dan Sist. Inf., vol. 4, no. No. 1, pp. 149-158, 2017.

[15] C. Prell, "Becoming Familiar with Social Networks," in Social Network Analysis: History, Theory and Methodology, 2012, pp. 7-18.

[16] M. T. Anwar, A. Iriani, and D. H. F. Manongga, "Analisis Pola Persebaran Pornografi pada Media Sosial dengan Social Network Analysis," Buana Inform., vol. 9, no. 1, pp. 43-52, 2018.

[17] S. P. Borgatti, M. G. Everett, and J. C. Johnson, "10 Centrality BT - Analyzing Social Networks," in Analyzing Social Networks, 2013, p. 304.

[18] S. P. Borgatti, M. G. Everett, and J. C. Johnson, Analyzing Social Networks, 2nd Editio. London: SAGE Publication Ltd, 2018.

[19] R. A. Hanneman and M. Riddle, Introduction to Social Network Methods: Table of Contents, vol. 13, no. February. 2005.

[20] F. N. Maulidya, W. Witanti, and A. I. Hadiana, "Pembangunan Sistem Informasi Pola Hubungan Kerja Antar Tenaga Medis Pada Rumah Sakit Jiwa Provinsi XYZ Menggunakan Social Network Analysis," in Prosiding Seminar Nasional Sains dan Teknologi ke-9, 2018, pp. 214-219. 